\title{
"Quite a Ripple but No Revolution": The Changing Roles of Women in the Iowa Farm Bureau Federation, 1921-1951
}

\author{
JENNY BARKER DEVINE
}

AT THE 1921 IOWA STATE FAIR, Sarah Elizabeth Richardson, a farm woman from Mahaska County, Iowa, appealed for the inclusion of women in the Iowa Farm Bureau Federation (IFBF). She asserted that "the Federation machine, great and glorious though it is, will never be able to function 100 percent efficiently until the women have climbed into the bandwagon." In order to guarantee success for the entire organization, she urged IFBF leaders to "get the women, if you want to hold the men." Her speech prompted the organization's male leaders to act. The following spring, in April 1922, IFBF Secretary E. H. Cunningham convened a group of eleven women to discuss how women might contribute to the organization on the state level. That meeting led to the creation of an interim Women's Committee, which became permanent the following year. ${ }^{1}$

In 1937, after chairing the Iowa Farm Bureau Federation's Women's Committee (IFBFWC) for 15 years, Richardson still eagerly promoted mutuality and the importance of women

1. Sarah Elizabeth Richardson, Iowa Farm Bureau Messenger (hereafter cited as IFBM) 3 (September 1921), 1. I will refer to the Iowa Farm Bureau Women's Committee as the IFBFWC and the Women's Committee. Use of the phrase Farm Bureau women will most often refer to all women participating in IFBF activities at the township, county, and state levels.

THE ANNALS OF IOWA 64 (Winter 2005). (C) The State Historical Society of Iowa, 2005. 
within the organization. That year she wrote that both men and women must be "interested and active" members, so that the goal of "a happy, contented, prosperous family on every farm" might be achieved. Richardson concluded, "The women's committee in state, county, and township and school district is not a division, but rather a commission to carry out the program.."

Such comments illustrate how Iowa Farm Bureau women built on their roles as wives, mothers, neighbors, and farm workers to gain authority within the IFBF, which became the largest general farm organization in the state shortly after its founding in 1919. From the organization's earliest years, Farm Bureau women in Iowa viewed themselves as contributors, not merely as helpers, and they differed from those in other states because they established their committee as an equal component, not as an auxiliary, of the main organization. Their rhetoric proclaimed that they were not subordinate to men in the IFBF, and their programs on rural health, education, recreation, politics, and the home were an indispensable part of bettering the lives of Iowa farm people.

During the first 30 years of the Iowa Farm Bureau Federation Women's Committee, an era of consolidation and growth for the IFBF, women reshaped and managed Farm Bureau programs to meet their own interests. Women's programs began during the 1920s as practical activities, often led by home demonstration agents, which focused on family and home improvements. During the 1930s and 1940s, as women began to define themselves as agricultural activists with interests beyond the family and home, women's activities came to focus less on practical education and more on social activism, especially in the area of membership for the entire organization.

Similar studies by historians Mary Neth and Nancy K. Berlage have illustrated the complexity of women's roles within

2. Richardson, "Women and the Farm Bureau," Iowa Bureau Farmer (hereafter cited as IBF) 1 (January 1937), 15. The IFBFWC operated as a functioning committee, not an auxiliary of the lowa Farm Bureau Federation. Delegates from nine districts elected the nine members of the committee, and the chair served as a voting member of the IFBF Executive Committee. Women were also very active on the local levels. The role of vice-president of the county and township bureaus was usually reserved for women to ensure women's participation. 
state Farm Bureaus by considering how women used their feminine authority in the home to gain power within the organization. Yet both Neth and Berlage argued that this influence had gendered connotations and did not allow women full participation. Berlage, for example, noted that a complex rhetoric of partnership between men and women shaped women's involvement by allowing women to at times declare equality between the sexes and at other times to exploit their unique authority over the business of the home. That allowed a state Farm Bureau to capitalize on women's participation and to expand its appeal as a family and farm organization, integrating "those institutions that members believed were integral to agriculture." Likewise, Neth observed that within the Wisconsin Farm Bureau, women discussed agricultural issues, but were primarily relegated to an auxiliary organization devoted to issues of the community, home, and family. She found that Wisconsin women valued the importance of their work but often struggled to gain recognition for their efforts within the organization.

In its first 30 years, between 1921 and 1951, the IFBFWC followed similar patterns as its members sought to establish the Women's Committee as a legitimate part of the IFBF. Iowa women, however, founded the IFBFWC on the principle that it deserved equal recognition within the IFBF. In the early 1920s Sarah Richardson adamantly insisted that women's programs at the state, county, and township levels should not constitute auxiliaries to the main organization. Instead, members of the IFBFWC designated their committee as a working part of the IFBF, with the chairperson serving as an ex officio, and later a voting member of the Executive Committee. In general, women accepted responsibility for home demonstration activities, but defined themselves as agricultural activists, working for the betterment of agriculture and rural life as a whole.

Like the women in the studies by Berlage and Neth, Iowa Farm Bureau women often worked within gendered parameters

3. Nancy K. Berlage, “Organizing the Farm Bureau: Family, Community, and Professionals, 1914-1928," Agricultural History 75 (2001), 426-29, 407; Mary Neth, "Building the Base: Farm Women, the Rural Community, and Farm Organizations in the Midwest, 1900-1940," in Women in Farming: Changing Roles, Changing Structures, ed. Wava G. Haney and Jane B. Knowles (Boulder, CO, 1988), 339-56. 
and focused on gender-appropriate issues such as the home and family, education, civic improvement, and health. Yet they also expanded their reach into agricultural issues, often discussing and speaking out on inflation, the demand for cost-effective production methods, and the necessity of soil conservation. For example, in an address to a mixed audience of men and women at the 1923 annual convention, Bertha Cutler of Harrison County stated that the IFBF could ensure greater prosperity by promoting more efficient production methods. She praised Farm Bureau programs on bookkeeping, technology, and agricultural methods, as well as programs geared toward the home and community. Cutler asserted that Farm Bureau programs "enabled farmers of the Middle West to hang on and keep striving in the dark deflation days of 1920 and 1921," and she predicted a bright future for the organization in Iowa. ${ }^{4}$

FOUNDED IN 1919, the Iowa Farm Bureau Federation consolidated existing county organizations and became the social and political partner, as well as a partial financial contributor, to the government-sponsored Extension Service. Both groups agreed that traditional politics, education, and mechanization, not radical political action, would bring about positive changes for farm families. The IFBF prided itself on being a socially progressive yet politically conservative organization that promoted gradual change through education and established political channels. Leaders garnered support by identifying the IFBF as a non-partisan and family-oriented group that members joined, paid dues to, and voted in as family units.

\section{IFBM 4 (February 1923), 3.}

5. Lowell K. Dyson, "Farmers' Organizations," The Greenwood Encyclopedia of American Institutions (New York, 1986), 14. The importance of the partnership between the Farm Bureau and the Cooperative Extension Service must not be underestimated. Their complex and interdependent relationship began in the early twentieth century, when the Extension Service relied on donations from local and private donors to carry out its activities. To ensure greater statewide consistency in Extension activities, in 1913 the Iowa General Assembly passed legislation to create county farm aid associations, as well as a tax to support such organizations. These county associations, then, were required to raise set sums toward hiring and maintaining an Extension agent. Over time, the county aid associations, or farm improvement associations, became known as farm 
Women had been active in the county farm bureaus as leaders and members since the 1910s, but in January 1919 only one woman, a home demonstration agent, was present at the inaugural meeting of the IFBF. In 1920 the all-male IFBF Executive Committee adopted a resolution bemoaning the lack of interest on the part of "the farmer's wife in the Farm Bureau organization, due no doubt to the lack of knowledge as to the status of the farmer's wife in the ranks of the organization." Yet the Executive Committee's desire to increase women's participation was not based on a desire to promote gender equity. Because the Farm Bureau advertised itself as a family organization, its leaders deduced that more men would attend meetings if their wives and children were also invited. ${ }^{6}$

The programs of the IFBFWC, which was founded in 1922, proved extremely popular. By 1924, the Women's Committee had organized more than 1,100 townships, and in 1925 its programs reached an estimated 158,000 women in the state. Within just a few years of its formation, then, the Women's Committee had established itself as an integral and indispensable part of the IFBF. ${ }^{7}$

In general, male leaders throughout the 1920s recognized the presence of women with ample praise for their leadership

bureaus. Following World War I, the financial relationship became even more important. In 1919 the federal government terminated wartime funding to the Extension Service. Fortunately for Extension, 1919 was the year in which the newly formed IFBF consolidated county farm bureaus under state leadership and began to recruit members in record numbers. Throughout the 1920s, in many counties, Farm Bureau dues paid for Extension agents' salaries, as well as for office space and educational materials. In 1924, for example, Extension Director R. K. Bliss estimated that Farm Bureau memberships provided approximately $\$ 330,000$ for Extension activities, over $\$ 100,000$ more than the wartime funding from the federal government. In some areas, Extension agents and Farm Bureau leaders worked together so closely that many rural residents falsely believed that they needed to be Farm Bureau members in order to take advantage of Extension activities. For more on the history of the Extension Service and the relationships between the Extension Service and the Farm Bureau, see Dorothy Schwieder, 75 Years of Service: Cooperative Extension in Iowa (Ames, 1993), 20-22, 34-37.

6. Donald B. Groves and Kenneth Thatcher, The First Fifty: History of the Farm Bureau in Iowa (Des Moines, 1968), 51; Sarah Elizabeth Richardson, IFBM 3 (September 1921), 1.

7. Groves and Thatcher, The First Fifty, 54. 
abilities and at least publicly put forth no resistance to the development of new programs. In a speech at the 1923 State Farm Bureau Convention, IFBF Secretary E. H. Cunningham told members that the organization should give women's work serious consideration since it was "unquestionably the most stabilizing influence in the organization." He favored the idea of mutual cooperation, with men working for the "farm problems" and women for the "home problems," and hoped to create the "most harmonious co-operation within the ranks of a farm organization. ${ }^{\prime 8}$

A reporter writing about the 1923 convention noted the increased numbers of women in attendance. He described how the women's notebooks and pencils were in "constant use," and lightheartedly warned, "If the 'lords of creation' don't look alive one of these days the lady workers will be reaching for the steering wheel." Three years later, in 1926, when more than 300 women attended the annual convention, an observer noted, "I have listened all over the place and haven't heard a single man show any resentment or antagonism toward the women. Can't say as much for some conventions of city folks."

Women also established county programs and took part in local Farm Bureau activities without arousing much, if any, heated debate among male leaders. More often, county leaders and Extension agents complimented the women's work and tried to ensure that women's programs received equal attention. In an address to the IFBF in January 1924, R. K. Bliss, the director of the Cooperative Extension Service, called the establishment of the IFBFWC "one of the most constructive acts" of the Iowa Farm Bureau. "Women," he claimed, "have been one of the most important factors in developing township and community meetings. What would our township and community meetings amount to if it were not for the women?" In fact, in most coun-

8. Annual Report of Home Economics Extension Work, 1923-1924, Cooperative Extension Service in Agricultural and Home Economics Records, RS 16/3/0/1, University Archives, Special Collections, Parks Library, Iowa State University, Ames (hereafter cited as Cooperative Extension Service Records).

9. "Women's Part in Bureau Growing," IFBM 4 (February 1923), 1; "The Women's Side of the Farm Bureau Convention," Iowa Homestead, 1/21/1926. 
ties the chair of the women's committee also served as the vicepresident of the entire county organization, and women often served on budget and leadership committees. ${ }^{10}$

The main obstacles for women during those early years were not vocal male opponents or reluctant female leaders but rather shortages of active male supporters to help establish specific programs, appoint leaders, and allocate financial resources. Even in 1924, when women's activities had become firmly established and only two counties remained unorganized, Richardson reported that the women's programs were "handicapped by total lack of working funds." The IFBFWC adopted a unified state plan in 1923, but its provisions were vague and focused on local improvements rather than the consolidation of local organizations under state leadership. The committee's local emphasis should not be surprising, since that was the most economical and efficient way to develop leadership. Because the Extension Service and county dues funded those local programs, they required no financial assistance from the state federation. ${ }^{11}$

10. R. K. Bliss, "Farm Bureau Educational Program, an Address," Iowa Farm Bureau Federation at Des Moines, 1/16/1924, MS 105, Iowa Farm Bureau Federation Records, Special Collections, Parks Library, Iowa State University, Ames (hereafter cited as IFBF Records). Local male leaders often made similar positive comments regarding women's work. See W. H. Stacy and H. J. Metcalf, "Farm People Testify to Farm Bureau Work," Burlington Hawk-Eye, 2/13/1926; H. J. Metcalf, "Farm Bureau Leaders Here," Estherville Enterprise, 12/30/1925; Mrs. A. A. Graham, "Women are Busy in Farm Bureau Work," Kossuth County Advance, January 1923, clippings in IFBF Records.

11. Memorandum, "Farm Bureau Women Adopt Unified State Plan," 1923, IFBF Records; "Township Organization for Home Project Work," 1923, ibid. Although the Iowa Farm Bureau had no shortage of women leaders, the organization still met some resistance. For example, in 1922, when Ruth Buxton Sayre became the women's chairperson of Virginia Township in Warren County, she found it extremely difficult to secure the five local leaders and nine school district cooperators necessary to organize the township. Sayre later recalled her first day of canvassing the township in her Model T Ford, with her young daughters in the back seat. She met women who felt they were too busy or too ill for Farm Bureau activities and others who refused because their husbands would not want them to do "anything like that." In addition, membership in the Farm Bureau, at five dollars per year, may have been too expensive for some farmers struggling to repay debts and mortgages. (Five dollars in 1923 is, according to The Inflation Calculator at www.westegg.com/inflation, equivalent to a little over $\$ 50$ in 2005.) Julie McDonald, Ruth Buxton Sayre: First Lady of the Farm (Ames, 1980), 39-42; IFBM 7 (December 1925), 2; Dorothy Schwieder, Iowa: The Middle Land (Ames, 1996), 148-50. 
The day after Richardson's speech at the 1924 convention, the Executive Committee, convinced by "a very insistent demand for increased service and wider activities," appropriated $\$ 4,000$ as a tentative budget for women's activities. According to a notice in the Iowa Farm Bureau Messenger, the officers and committee members had been "looking forward to the time when the women's work in the Farm Bureau could be given something more tangible than just words of praise." With their budget secure, the IFBFWC adopted a new five-point program: to consolidate and solidify the general policies of the Women's Committee; to cooperate with other women's organizations; to develop a system of diplomas for work done by Farm Bureau women; to support a special study of marketing; and to adopt a standardized report form, to be used by women statewide. Funding allowed the women's committee to act more effectively on its state plan and to work toward eventual uniformity of programs across the state, activities that would define the IFBFWC throughout the 1930s and 1940s. During the middle to late 1920s, however, it still focused on developing county leaders. ${ }^{12}$

To build county organizations, Farm Bureau women relied on a highly developed system of training schools created by the IFBFWC and the Extension Service. County Farm Bureau leaders, in conjunction with home demonstration agents, formed educational and organizational networks with representatives from the state, townships, and school districts. Courses lasted for five months and usually consisted of one all-day meeting each month. During the rest of the month, township leaders trained school district cooperators and gathered feedback before the next lesson. This provided local women with a means of voicing their opinions about the lesson and developing their own curriculum.

12. "Women Took Active Part in Convention," "Special Appropriation for Women's Work," and "Women Plan Work for the Year," IFBM 5 (FebruaryMarch 1924), 6. The IFBFWC sought to consolidate state programs by creating uniform county organizations, with a woman serving as vice-president and a five-woman committee in charge of selecting projects. Their objectives also included provisions to work with men whenever possible to strengthen the organization. 
The development of the training school system depended on the active participation of the Extension Service. Although the Extension Service claimed to work with various organizations, including the Grange and the Iowa Farmers' Union, the Farm Bureau enjoyed a close administrative partnership with, and made significant financial contributions to, Extension activities. The training school system grew out of this partnership and benefited both parties in their efforts to reach rural families. Neale S. Knowles, the head of the Home Economics Division of the Iowa State Cooperative Extension Service from 1908 to 1935, initially developed the method of filtering information through local instructors because it allowed agents and county leaders to reach 15 to 20 times the number of households they could reach on their own. Farm Bureau leaders likewise used this method to recruit new members, and they relied on the practical Extension activities to attract individuals who might not otherwise be interested in a social and political organization. ${ }^{13}$

The training school system met with immediate success and expanded rapidly during the 1920s. The first training school in Iowa took place in Monroe County in April 1921. That year, 2,050 women attended training schools in 18 different counties. Projects included clothing, sewing, home management and furnishing, nutrition, and poultry. In 1922-1923 Neale Knowles reported an "unusual awakening of interest in the counties without agents," as 40,985 women attended 2,566 training schools just on clothing; nutrition training schools attracted 12,906 women that year; 4,862 were present for home furnishings, and 2,916 for schools to strengthen the Farm Bureau. ${ }^{14}$ The sudden surge in popularity may be attributed to several factors - better communication, automobile ownership, and improved roads - but also to a rising awareness of inequality between urban and rural standards of living.

13. Schwieder, 75 Years of Service, 36-37.

14. "Women of Iowa Farms Have Shown Great Enthusiasm in Furthering Interests of Better Agriculture," 1922, Cooperative Extension Service Records; "Statistical Report of Project Work Done by Specialists and Home Demonstration Agents, 1922-1923," ibid.; Neale S. Knowles, "Annual Report of Work Done by Neale S. Knowles, State Leader of Home Demonstration Agents, 1922-1923," ibid. 
By attending home demonstration programs, women could not only learn how to quickly and cheaply modernize their homes and methods, but also learn about leadership and community involvement. They used the meetings as opportunities to build associations with other farm women and farm families for a deeper sense of pride and solidarity. In 1922 Kossuth County chair Evelyn Graham reported that the monthly Farm Bureau meetings filled a "long felt want" and provided women with a chance to develop "community spirit and a desire to help each other." Home demonstration programs that encouraged women to be "well dressed" and "well fed" provided a much needed boost to their confidence that they too could "enjoy the world outside the four walls of her own home as her city sisters do." ${ }^{15}$

Although most women participated in programs geared toward the home, they viewed home demonstration programs as essential to overall community improvement. At the IFBF's annual convention in 1926, Richardson told members that because women made consumer choices about spending for the home, they should be "good businessmen," not only as homemakers, but also as partners in the farming enterprise. By efficiently managing the farm and getting involved in the Farm Bureau, women could work to ensure greater profits for farmers through reduced freight rates, equalized taxation, and "legislation that takes notice of the farmer's needs." At the same convention, Farm Bureau member Minnie Friedley of Black Hawk County spoke to the women about the importance of nutrition in rearing healthy, responsible children. After she pointed out that the state often intervened on behalf of poorly fed children, one woman in the audience remarked, "Well, it never occurred to me before that I was saving taxes when I made the baby take his vegetables! $!^{\prime 16}$

By the end of the 1920s, due to demand from local women's groups, training schools also began to include lessons on devel-

15. Dorothy Schwieder, "Changing Times: Iowa Farm Women and Home Economics Cooperative Extension," in Midwestern Women: Work, Community, and Leadership at the Crossroads, ed. Lucy Eldersveld Murphy and Wendy Hamand Venet (Bloomington, IN, 1997), 207; Mrs. A. A. Graham, "Women Are Busy in Farm Bureau Work," Kossuth County Advance, June 1922, 23.

16. "Mrs. Richardson's Report" and "The Women's Side of the Farm Bureau Convention," Iowa Homestead, 1/21/1926. 
oping good citizenship through voting and political awareness, as well as on the nature of good government, democracy, and parliamentary law. In 1925 the first statewide citizenship course for women surveyed the organization of governments and the levying of taxes at the township, county, state, and federal levels. The course also discussed how Farm Bureau members could become involved at each level, and strongly encouraged women to take "seriously the privileges of citizenship recently granted to them. ${ }^{\prime 17}$

Programs did not encourage farm women to challenge existing political systems, but rather to understand and use them to secure funding for rural education and health, as well as to advocate farm policies to ensure stable commodity prices. Leaders strongly encouraged women to exercise their voting rights, especially for the good of the farm. In an address at the 1926 annual convention, Addie Wood of Moville asserted that women should vote responsibly and have a "unified purpose and an active program." By organizing around community issues such as health, education, and agriculture, Wood believed that the farm woman could "do her share toward placing the American farm home in a proper position to aid in the demand for agricultural equity." ${ }^{18}$

Farm Bureau programs also encouraged women to become more involved in community affairs by seeking leadership positions at the local level. To that end, female township leaders and school district cooperators joined their male counterparts in attending county leadership training schools. There, with state leaders at the helm, they discussed the development of local meetings, the duties of leaders and committees, the nature of community ideals, agricultural issues, and leadership within rural organizations. Leadership schools also provided practical experience in conducting meetings and making contact with state leaders and prominent members of the community. Although they shared these meetings with men, in many instances

17. "Citizenship Course for Rural Women Planned by Bureau," IFBM 6 (July 1925), 3.

18. "Says American Farm Housewife Has Many New Responsibilities," IFBM 7 (February 1926), 3. 


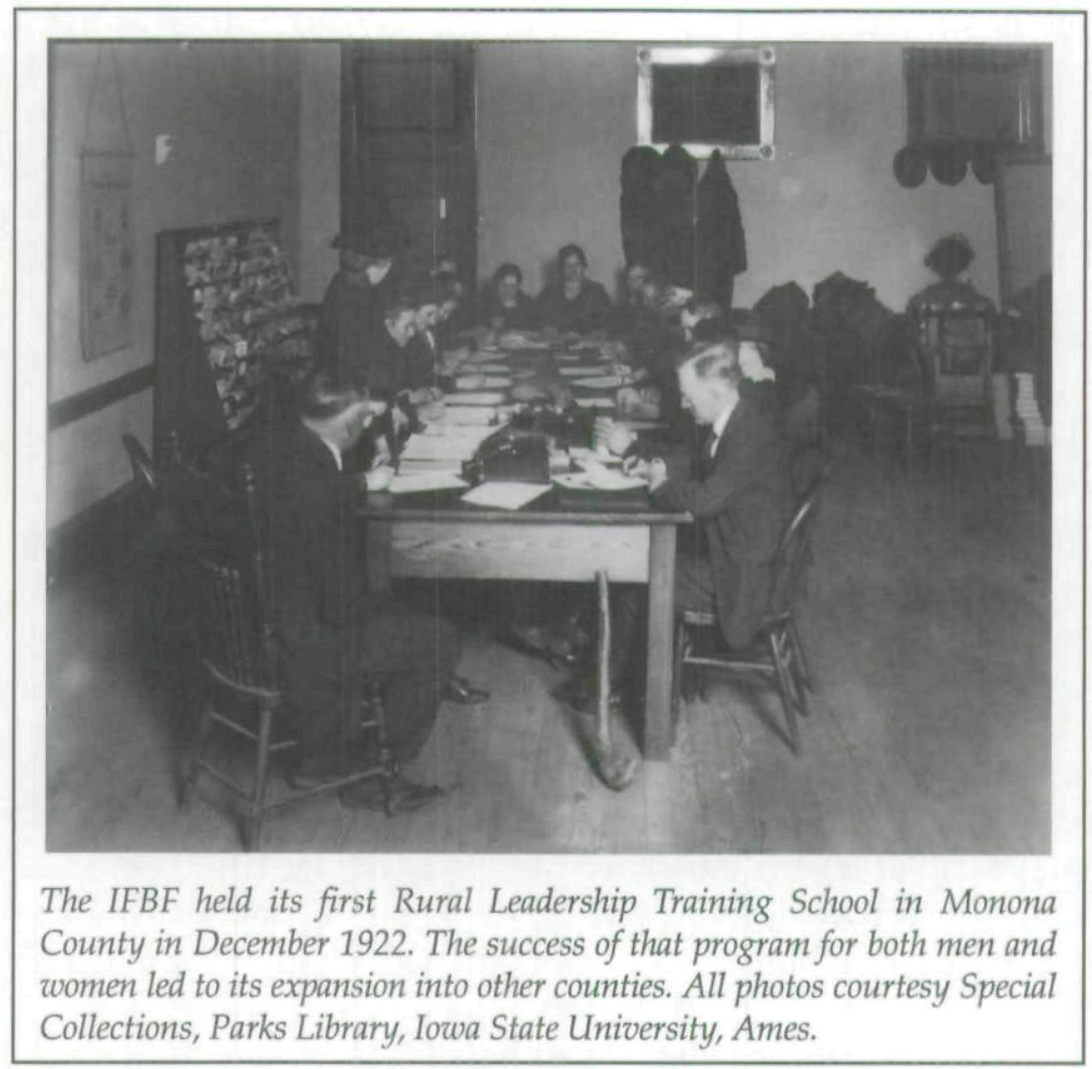

women dominated the proceedings. Photographs from training schools in Mahaska, Fremont, Plymouth, and Monona counties between 1922 and 1928 reveal the strong and active presence of women. This trend continued through the following decade, with 144 women and 125 men attending leadership training schools in 18 counties during the winter of 1932 and 1933. Although the Extension Service cosponsored many of these activities, training schools played an important role in building and maintaining Farm Bureau membership. ${ }^{19}$

19. The 18 counties were Hancock, Muscatine, Howard, Chicksaw, Floyd, Greene, Boone, Ida, Sioux, Shelby, Buchanan, Story, Wayne, Davis, Monroe, Carroll, Sac, and Calhoun. Women outnumbered the men at eight of the meetings, an equal number attended at two meetings, and men outnumbered women at seven meetings. The largest margin was in Sioux County, with 21 women and 10 men attending. Photographs and County Leadership Training School Rosters, 1922-1933, IFBF Records. 


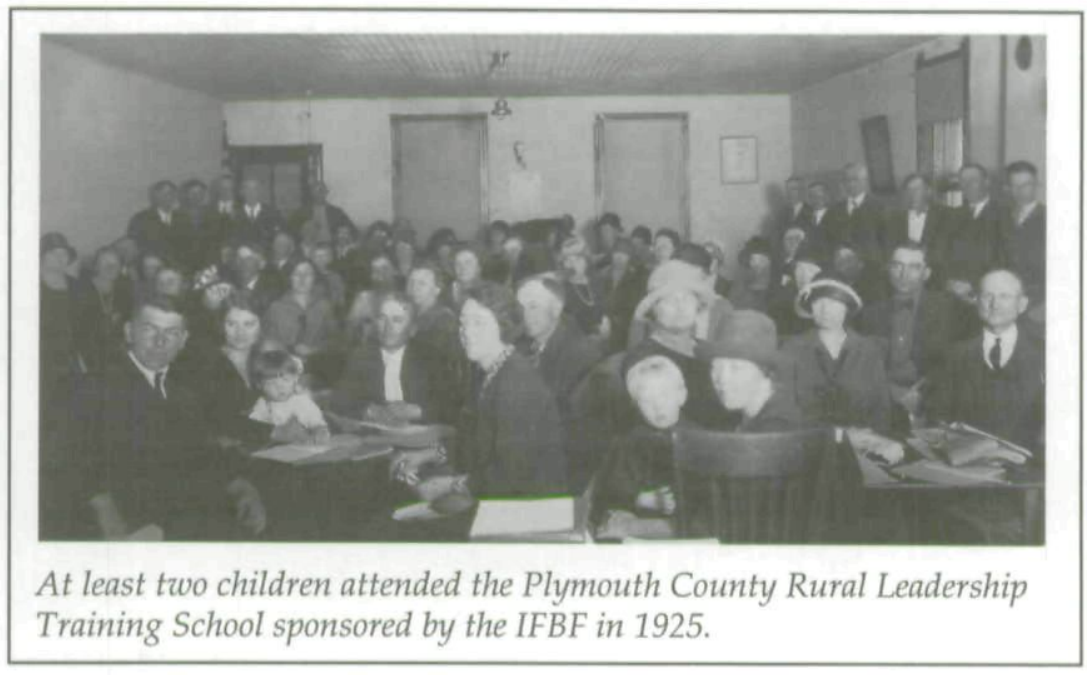

AS THE AGRICULTURAL DEPRESSION of the 1920s and 1930s took its toll on Iowa farm families, women's activities became even more important to the IFBF. At the onset of the Great Depression, between 1930 and 1933, paid family memberships in the IFBF plummeted from 63,968 to 18,016 , the lowest point in the organization's history. For those who were able to stay on the farm, women's work with poultry, produce, and homemade goods was often an integral part of keeping the family farm solvent. Women's work not only reduced cash expenses, but often provided a regular cash income. Deborah Fink and Dorothy Schwieder have argued that in spite of the decade's economic conditions, living conditions and social status actually improved for many rural women. Owing to their ability to "make do," they no longer believed themselves inferior to urban women. At the same time, improved roads and the spread of rural electrification meant greater mobility and less time spent on daily chores, which in turn provided more opportunities to participate in social activities. ${ }^{20}$

Just as many women sustained the family farm, so too did they sustain farm organizations. Although IFBF membership numbers dropped sharply during the Great Depression, many

20. Deborah Fink and Dorothy Schwieder, "Iowa Farm Women in the 1930s: A Reassessment," Annals of Iowa 49 (1989), 577, 579-80. 


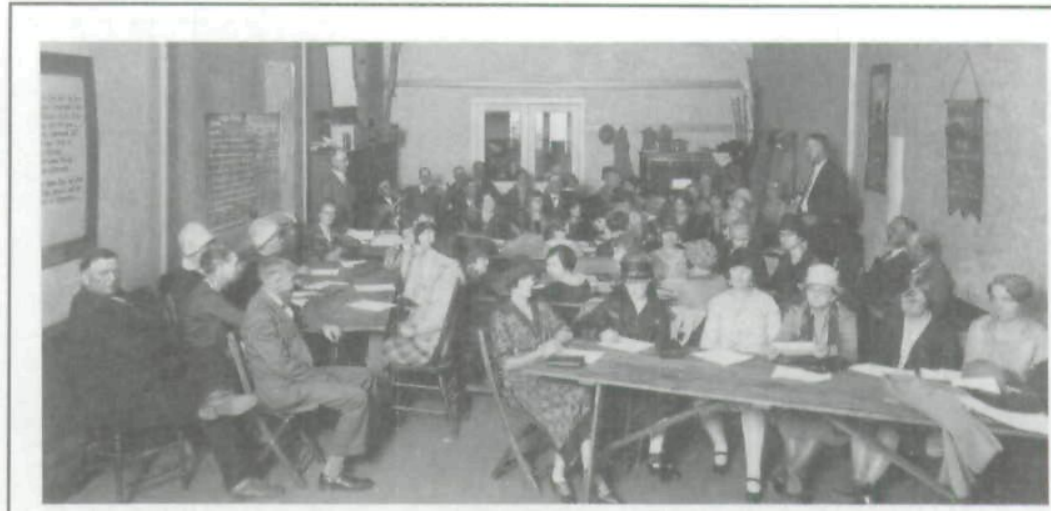

Women predominated at the Mahaska County Rural Leadership Training School sponsored by the IFBF in October 1928.

women still participated in home demonstration programs sponsored in conjunction with the Extension Service. They also carried on with organization work for the Farm Bureau. In 1929, for example, Cherokee County Extension Agent Clarence Turner proposed that the Farm Bureau try to develop more female leaders, since the women's programs "no doubt played an important part in keeping the membership at its present figure." Even in 1935, when the Cherokee County Farm Bureau had a membership of only 506 families, less than half of the average between 1921 and 1929, there were 116 female school district cooperators in 15 townships, 147 local leaders, and 1,286 women who attended demonstration meetings. Across the state in $1930,187,737$ people attended home economics demonstration meetings, and in 1931, 10,169 women still served as local leaders to help filter the lessons to the local levels. ${ }^{21}$

21. Specific developments, especially for women's activities, are difficult to track because between 1926 and 1936 the IFBF had no official publication to cover statewide news. Low membership numbers probably made it difficult to finance an official statewide publication, while most county farm bureaus relied on local newspapers to advertise their activities. Although it lost a significant number of members, the Cherokee County Farm Bureau continued to publish a monthly four-page newspaper and kept regular meeting minutes, and the County Extension reports are generally complete. Thus, the section of this article dealing with the years between 1926 and 1936 relies primarily on events in Cherokee County. "Cherokee County," County Extension Agents Narrative Reports (Ames, 1929), 32; Fink and Schwieder, "Iowa Farm Women in the 1930s," 583. 
By the mid-1930s, it was this sustaining influence that gave women greater leverage in the state organization. Falling membership in the early 1930s meant less revenue from membership dues and Farm Bureau commercial services, cooperatives, and insurance. By the middle of the decade, the IFBF was in a precarious financial position. In 1935 IFBF Secretary-treasurer V. B. Hamilton began to reorganize the financial and administrative structures of the Farm Bureau. First, he created a resolutions committee, made up of ten men and one woman, to formulate policies. Second, he established an administrative board to manage the budget and business aspects of the organization. Of primary concern was uniform record keeping for the commercial services at the county level in order to prevent instances of "misappropriation" by trusted employees. Also concerned about the future of the Women's Committee, Hamilton found ready leadership in Ruth Buxton Sayre, who assumed leadership of the IFBFWC in 1937. For Farm Bureau women, centralization allowed for greater communication and encouraged growth over the next ten years. ${ }^{22}$

Sayre, an Ackworth farm woman and mother of four children who had married into agriculture in 1918, had long been interested in reshaping the women's programs. In 1933, perhaps due to the dismal membership numbers, she persuaded IFBF President Charles E. Hearst to grant the chair of the Women's Committee a voting seat in place of the ex-officio position on the Executive Board. Rather than describing it as a significant event, however, Sayre seemed to believe it had been inevitable. She later said, "In the pioneer tradition of Iowa, women were always partners on the farm.... Why shouldn't they be partners in the Farm Bureau? I was pleased when women were released from their water-tight compartment and allowed to become involved in the whole Farm Bureau program, because that was the Iowa way." A voting seat on the Executive Council gave women an official voice on organizational matters and allowed them to expand their influence at the state level. ${ }^{23}$

22. Groves and Thatcher, The First Fifty, 187, 195, 197.

23. McDonald, Ruth Buxton Sayre, 53. 
In her first year as IFBFWC chair, Sayre set out to centralize women's activities by developing township farm bureaus and improving the women's bureaucracy. She wanted to see the establishment of a Farm Bureau-along with a strong program for women-in every township in Iowa. Sayre admitted that she had "no training in business administration and learned it the hard way," but she called for systematic organization that required women to record the minutes of their meetings and receive training from Extension agents and IFBF staff members. Sayre was successful because women responded to her empowering language and her accessible leadership style, and also because the IFBFWC offered Iowa farm women one of the few outlets for moderate political and social activism during the Great Depression, World War II, and the immediate postwar period. ${ }^{24}$

During the late 1930s, Roger Fleming, head of the IFBF's newly created Research Department, worked with Sayre to create six pamphlets for county leaders on the subjects of health, libraries, taxes, international trade, rural roads, and Farm Bureau membership. Through these booklets, which also provided questionnaires by which leaders might gauge their success, the Women's Committee could more evenly disseminate its programs. The approach appeared to work. In 1937, 726 townships reported active women's committees; after two years, the number had grown to 1,010 (out of 1,016 township Farm Bureaus). This period also saw remarkable growth in the main organization. Figures from January 1937 showed a 44 percent increase in membership, from 30,830 in 1935 to nearly 45,000 individuals and families in 1936. Not only did the IFBF have the largest membership gain in the country, but the organization also seemed to have recovered from slipping numbers caused by hard economic times. ${ }^{25}$

24. Ibid., 57,61 .

25. Ibid., 58. During the Great Depression, the IFBF retained its status as the largest general farm organization in the state, even though membership plummeted from approximately 63,000 families in 1930 to 18,000 in 1933 . Robert L. Tontz, "Memberships of General Farmers' Organizations, United States, 1874-1960," Agricultural History 38 (1964), 156; "Report of the State Chairman," IFBFWC, 1939, IFBF Records. 
Communication was the most essential element in consolidating the overall authority of the IFBF. It had been without a central publication since 1926, when it had discontinued its four-page monthly newspaper, the Iowa Farm Bureau Messenger. Then, in 1937, the organization introduced an Information Department responsible for producing a monthly magazine, the Iowa Bureau Farmer. Each month, the new magazine featured a column by president Francis Johnson, photographs, features on various leaders, and articles on the IFBF's political and social activities. The magazine enjoyed a large circulation because each family membership included a subscription. In 1939 the Iowa Bureau Farmer had a circulation of 35,000. By 1942, circulation stood at 53,442, and in 1943 it had increased to nearly $64,000{ }^{26}$

THE WOMEN'S COMMITTEE also used this new medium. Its main spokesperson was Bess Newcomer, who published 97 columns between 1937 and 1950, writing on a nearly monthly basis after 1941. Her columns are especially useful for understanding the shift in women's activities between 1921 and 1951. Born on a farm west of Moulton in 1893, Newcomer was raised by her mother, a widow, who managed the farm with the help of family and neighbors. Her mother also supported the family by selling dairy products and eggs to a hotel in Moulton. In 1913 Newcomer graduated from Drake University in Des Moines and taught school for several years before returning to the farm in 1922 with her husband, Ralph Newcomer. Shortly thereafter, she became involved with the county Farm Bureau women's organization, and, in 1937, the women of her district elected her to become the Eighth District Committeewoman. She served in that capacity until $1948 .^{27}$

26. "Iowa Bureau Farmer and Publicity," IFBF Administrative Reports, 1940, 1942, 1943, IFBF Records.

27. "Prospectus" for My 70-Year Affair with the Wabash, Bess Newcomer Papers, Iowa Women's Archives, University of Iowa Libraries, Iowa City. In her article on Wisconsin Farm Bureau women, historian Mary Neth emphasized the importance of early life experiences in shaping farm women leaders' perceptions of work, gender, and organization. For example, Neth found that because Farm Bureau leader Isabel Baumann had, as a child, worked in the fields alongside her mother, she did not believe that women's work was limited to the home, garden, and chicken house. Rather, she had an all-encompassing sense of wom- 
During the 1930s and 1940s, Newcomer was not the only woman writer featured in the Iowa Bureau Farmer, but she was the first woman to be a regular columnist. She always chose her own topics and illustrations, and she claimed that the editors did not restrict content or length. Furthermore, Newcomer declared that her column was "not a column for women, as editors' surveys showed men [readers] in equal numbers." The majority of her columns were on the subject of membership, which included commentary on the organization, leadership, and the obligations of members. ${ }^{28}$

Newcomer's writings illustrate how the IFBFWC evolved from a women's organization devoted to home, family, and local issues into an organization concerned with major social, political, and agricultural issues. Her early columns tended to focus on building membership, using tax dollars to create rural libraries, supporting the war effort, and advocating good citizenship, soil conservation, and responsible farming practices. In the immediate postwar years she devoted more attention to consolidating rural schools, promoting fair tax policies for farmers, sustaining the ideal family farm, and maintaining leadership within the organization. The issues changed in their relevance, especially as technology and the modernization of the rural home affected how women functioned within the IFBF. Like Sayre, Newcomer advocated organization and centralization as keys to achieving the IFBFWC's goals. She always supported

en's work on the farm. Likewise, in Newcomer's writing it is clear that she understood how her mother's work and sacrifice shaped her perceptions as an adult. Newcomer dedicated her second column in the Iowa Bureau Farmer, in July 1938, to her mother for instilling in her children an appreciation for work and nature and a sensible "philosophy of life." Newcomer wrote, "She was short on money, so she gave us work; she was long on sense, so she gave us leisure. We were poor but never knew it." If she and her brother complained about the difficult farm labor, "[Mother] pointed out how spindly was the corn growing in the shade of orchard trees." Neth, "Building the Base," 342-45; Newcomer, "Hobby or Heritage: A Tribute to My Country Mother," IBF 2 (July 1938), 9.

28. "Prospectus." The editors' surveys are no longer available to confirm her statements, but see IFBF Administration Report, Annual Conference, Des Moines, November 1943, in which the Information Department included a statement specifically thanking Newcomer, "whose monthly features have been outstanding." No other writer or contributor during this era ever received such recognition. 
Sayre as a leader with a natural ability to "gauge the processes of our growing or for our failure to grow." ${ }^{129}$

For Sayre and the members of the IFBFWC, camaraderie was essential to centralization and growth. In 1941 the committee established a State Camp for Farm Women in order to bring county leaders together at a time other than the annual convention. The 173 women who attended the first camp slept in bunks at the Iowa State Fairgrounds. During the weekend they spoke with IFBF leaders, toured the state offices, and selected programs on nutrition and libraries for the coming year. Newcomer overwhelmingly approved of the camp's proceedings and described how the women's visit to the state office gave them a new respect for the work of male leaders. Although the accommodations were rustic, members of the Women's Committee found it beneficial to hold a women's meeting entirely removed from IFBF conventions, and the summer conference became an annual event. ${ }^{30}$

In 1942 the IFBFWC abandoned the bunk beds at the Iowa State Fairgrounds and moved the "camp" to the Hotel Kirkwood in Des Moines, where women "enjoyed meals they didn't plan and dishes they didn't wash." The hotel staff also welcomed the farm women because they were the only guests who made their own beds and left the rooms spotless. In addition to training activists, then, the summer conferences offered women an opportunity to get off the farm and remove themselves from their daily responsibilities. ${ }^{31}$

One of the first public projects for the Women's Committee was the founding of libraries in rural areas. That issue had been on its agenda for a number of years, but in 1938, and again in 1940 and 1941, the Women's Committee took its concerns to the state government. In June 1940 Newcomer wrote that "America's very destiny may hinge on making sure that he who ploughs also reads." She argued that only state and federal aid could equalize library services in rural and urban areas. Noting that

29. Bess Newcomer, "Farm women put 2 and 2 together and get answer, first state camp for farm women proves big success," IBF 5 (August 1941), 6.

30. Ibid. No other state Farm Bureaus at this time held such meetings for their women's committees or auxiliaries. Iowa was the first to do so.

31. Bess Newcomer, "We Marshall Our Reserves," IBF 6 (August 1942), 5. 
library programs would ensure not only education but also the preservation of democracy, the 1941 Women's Committee handbook called for the establishment of free regional libraries staffed by trained librarians with an outreach system of bookmobiles and branches in schools, stores, gas stations, and other accessible locations. ${ }^{32}$

On February 20, 1941, ten committeewomen traveled to the state capital to meet with Governor George A. Wilson and several legislators to promote a bill for a "literacy tax," a general tax to support the creation of more rural and mobile libraries. The legislators did not comply. Newcomer refused to accept Wilson's claim that defense and agricultural issues needed more immediate attention. "We must go on," she argued; "to quit is not in the fiber of country women." The Women's Committee would keep rural libraries and literacy on its agenda through the 1950s, even though its proposed legislation would also fail to impress Governors Bourke Hickenlooper and Robert D. Blue. In 1942, due to wartime shortages of labor and supplies, the women shelved the issue of rural libraries for the duration of the conflict. Instead, they promoted annual township reading contests, believing that such contests would foster a demand for libraries among rural families. That same year, the Women's Committee also began a scholarship fund to pay for two years of college for promising rural youth who worked to become teachers. By the late 1940s, the IFBFWC had shifted its strategy, and instead of regional libraries, it began to focus its efforts on rural school consolidation. ${ }^{33}$

Meanwhile, the realities of World War II shaped IFBFWC activities. At the summer conference in 1941, the women adopted the topic "Health for National Defense" for the statewide Home Project studies; and for the 1942-1943 study they developed a "War Emergency Program," which entailed lessons on first aid, home nursing, milk sanitation, and other adjust-

32. Bess Newcomer, "Books are Tokens of Mental Riches-Plows, Symbols of Power," IBF 7 (June 1943), 9; Iowa Farm Bureau Federation Women's Committee Handbook, 1941, IFBF Records.

33. McDonald, Ruth Buxton Sayre, 64; Bess Newcomer, "Mother Visits the Legislature," IBF 5 (April 1941), 5; idem, "Books are Tokens of Mental Riches," 9; Iowa Farm Bureau Federation Women's Committee Handbook, 1941. 
ments for the homemaker in wartime. Although they fully supported the war effort, Sayre, Newcomer, and others also spoke out for peace. In June 1939 Cara Brown wrote an article in the Iowa Bureau Farmer titled, "World Peace Through a Farm Woman's Eyes." After studying the materials on international relations provided by the IFBFWC, Brown argued that although isolation was not a productive response to the situation in Europe, neither was war. She demanded that newspapers give as much attention to peace as to war, and urged all nations to find a peaceful solution to the conflict. She believed that Iowa farm women should promote peace because farm families relied on the stability of foreign markets. Yet she also found that the women in her Farm Bureau study group would willingly embrace isolation if it spared their sons from the hardships of war. Iowa farm women, Brown wrote, "would gladly make sacrifices, would even go barefoot ... if they were positive that such a sacrifice would save their own sons and other mothers' sons from slaughter. ${ }^{\prime 34}$

Once the United States entered the war in December 1941, Newcomer expressed mixed reactions. In her January 1942 column-her first following the Japanese attack on Pearl HarborNewcomer wrote without patriotic fervor. She was primarily concerned with how the IFBFWC might adjust programs and to what extent it should. Newcomer hoped that Farm Bureau members and farm families could carry on just as they had in peacetime, but she also knew that many important decisions lay ahead. Farmers would need to choose between investing in war bonds or in labor-saving machinery, while farm organizations would confront even greater challenges to their demands for improved education and health as well as a fair farm policy to protect agriculture from the "economic impacts of war." ${ }^{135}$

Overall, Newcomer's columns reflected the policies of the IFBF, which supported the war effort. She urged farm families to be vocal patriots and demand respect as war workers. They should hang service flags in their windows and display their

34. Ruth Sayre, "Women's Committee," in Iowa Farm Bureau Federation, Annual Report (Des Moines, 1942), 15, IFBF Records; Mrs. Rollin Brown, "World Peace Through a Farm Woman's Eyes," IBF 3 (June 1939), 6.

35. Bess Newcomer, "Marble and Mud," IBF 6 (January 1942), 6. 
Production Certificate Awards, granted by U.S. Secretary of Agriculture Claude Wickard. Yet she also knew that farm families faced different circumstances from most Americans, and in the face of poor attendance at local meetings, she urged families to remain active in the Farm Bureau in order to advance the place of agriculture in American society. In her February 1942 column she encouraged farmers to continue their daily routines, despite criticism from non-farmers who did not believe that farmers made viable contributions to the war effort. Quite often, she wrote, when farmers went to register for the draft "with the dust and the tiredness of a day in the field settled on them," another man would tell them "what chumps they are to be farming instead of grabbing some of this easy defense money." ${ }^{136}$

Countering such criticism became a common theme in her columns throughout the war years, especially as labor shortages hindered many farmers from meeting increased production goals. Although farm workers received draft exemptions and farm families saw a significant increase in income due to federal policies that regulated prices and production, many problems still remained for agriculture in Iowa. In January 1943 Newcomer criticized federal policies that set production goals but did little to encourage laborers to stay on the farm. She cited examples from across the country where crops went ungathered and animals suffered because there were not enough hands to do the work. Newcomer believed that part of the problem could be alleviated if "farm boys" were given greater recognition for their service in the form of an emblem to wear for serving in an "essential war capacity." Yet such recognition was little consolation in a wartime system where "free enterprise is destroyed because the government determines the storage, distribution, and price of our products." In March 1943 she echoed those sentiments. "We know too well," she wrote, "no amount of prodding (or subsidies either) is going to get the job done if farmers are deprived of the very means of increased production-enough help, enough machinery, fair prices, decent health and education."

36. Bess Newcomer, "Caught Off Guard!" IBF 6 (February 1942), 7.

37. Schwieder, Iowa: The Middle Land, 276-79; Bess Newcomer, "Scars and Stars of Agriculture," IBF 7 (January 1943), 9, 17; idem, "Please Pass the Ammunition!" IBF 7 (March 1943), 7. 
Newcomer believed that while farmers were willing to do their share in the war effort, they should be wary of increased production goals that could lead to economic disaster during peacetime. As early as February 1942, she asked farmers to plan ahead carefully, and she urged the Farm Bureau to begin lobbying for a favorable postwar farm policy, in order to avoid an economic depression like the one that followed World War I. In July 1944 she called on Farm Bureau members to "lead out in after-war planning" and work for a clearly defined postwar plan from the government. She asked, "Why does our government expect us yearly to invest heavy capital and much labor in food production yet have so little to say in sketching the blueprints of the program?" Then, in October 1944, Newcomer warned that if history should repeat itself, and the war should end without a favorable agricultural policy in place, farm families would suffer. To avoid calamity, farm families needed to organize and bring greater attention to their problems. "It is a kind of agricultural suicide," she wrote, "to ignore or underestimate the securing of prestige that should be accorded farmers and their contribution to America in war or peace. ${ }^{\prime 38}$

Such sentiments echoed IFBF policies, which called for greater recognition of agriculture as a viable war industry. At its 1941 annual convention, the IFBF adopted a resolution declaring that the government must balance the needs of industry, labor, and agriculture in order to maintain an adequate national defense. Then, at the 1943 annual convention of the American Farm Bureau Federation (AFBF), some farmers complained that government production demands were unrealistic in light of labor and material shortages, and that industry, which siphoned workers from the countryside, benefited at the expense of farm families. Newcomer reflected these ideas in 1944, when she wrote that farmers needed to "organize" in the same fashion as industrial workers, so that agriculture might reach the "prominence-level of industry and labor. ${ }^{\prime 39}$

38. Bess Newcomer, "I Am a Farmer," IFB 8 (July 1944), 3; idem, "Practical Patriotism in War or Peace," IBF 7 (October 1944), 4.

39. Groves and Thatcher, The First Fifty, 109; Newcomer, "I Am a Farmer," 3. See also Bess Newcomer, "Why Educate Farmers?" IBF 8 (June 1944), 3; idem, "Scars and Stars of Agriculture," 9. 
ON WHICH SIDE OF THE FENCE

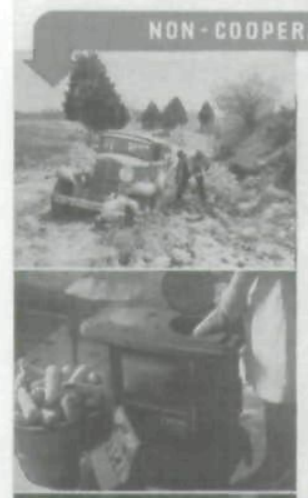

\section{ATOR}

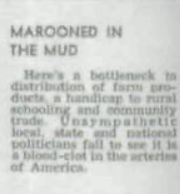

EURNING IOCENT

CORN IN THE

KITCHEN STOVE

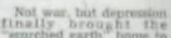

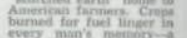

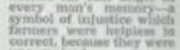

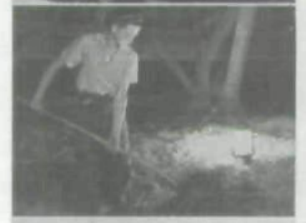

YOUR YOUNGSEESS

IN THE DARKNESS

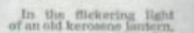

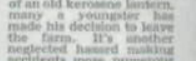

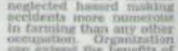

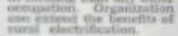

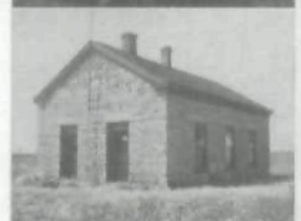

-AND THE DARKNESS

OF BACKWARD

to dincourane nod

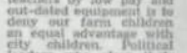

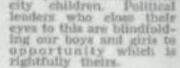

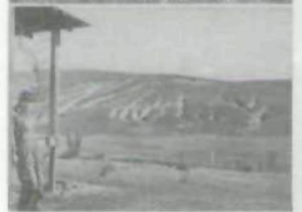

EROSION UNDERMIN-

ING YOUR SOIL AND

YOUR UIFE

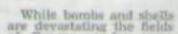

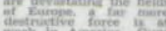

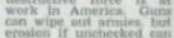

gester it unciectes as

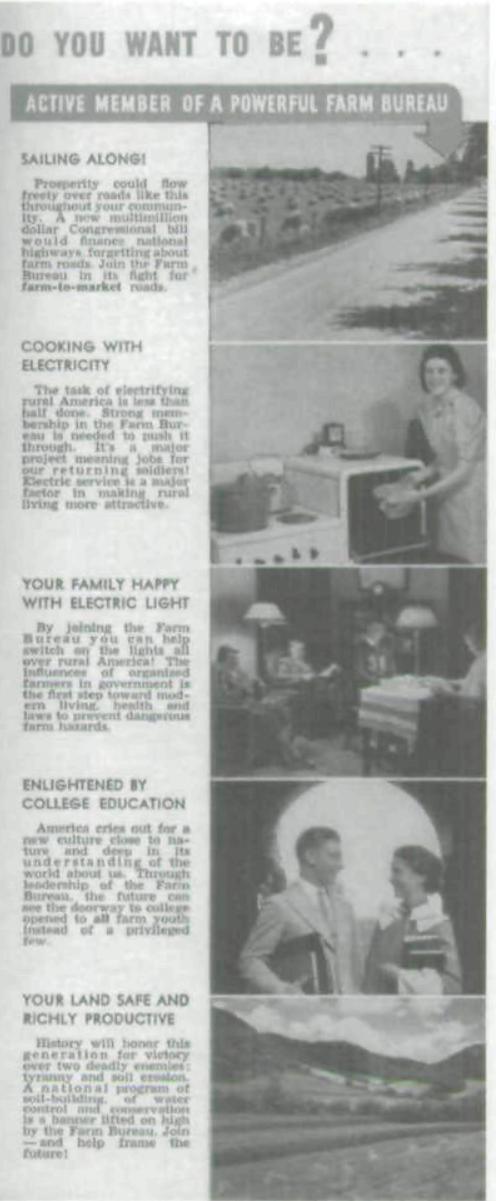

During World War II, the Farm Bureau increasingly used rhetoric similar to that of labor unions. For example, this 1944 American Farm Bureau Federation pamphlet, "Mission for a Million Farmers," encouraged farm families to organize socially and politically to avoid a postwar economic depression. According to this pamphlet, such organization would guarantee economic, social, and personal prosperity.

The language in Farm Bureau literature often resembled that of labor unions, warning farmers that depression would quickly return after the war if they did not consolidate their political voice. A 1944 AFBF pamphlet, "Mission for a Million Farmers," showed agriculture as a 1918 biplane trailing behind 
two B-29 Superfortresses, Industry and Labor. The pamphlet asked, "On which side of the fence do you want to be?" For non-cooperators, the future was bleak, characterized by rustic living conditions, dilapidated schools, and eroded farmland. For active Farm Bureau members, however, organization implied modernity: electrification would mean jobs and leisure; better schools would open the "doorway to college" for all farm youth; and conservation programs would ensure rich and productive farms. The IFBF hardly desired a return to normalcy after the war if such normalcy meant a return to the conditions of the 1920s and 1930s. ${ }^{40}$

The IFBFWC found the war years to be an opportune time to further women's essential roles in the IFBF. Drawing on growing popular opinion that elevated the status of women in American society, the IFBFWC produced booklets on patriotism and wartime responsibilities. In 1943 the Women's Committee Handbook was titled "VICTORY in the Hands of Women," although it still addressed the standard programs on health, libraries, music, and organization, rather than mobilization on the home front. Promoting the new handbook in her column, Newcomer wrote that the title did not imply that women would dictate the course of war. Rather, farm women could ensure a speedy resolution if they spent "every energy to help produce more food and fiber and, at the same time, keep home and community on an even keel. ${ }^{\prime 41}$

Talk of the war was present at the women's summer conferences. In 1942 the women discussed the rationing of canning sugar, their fears for their young sons, and the need to "meet situations that won't stay static" on their farms. By 1943, the number of women in attendance had grown to 250, with representatives from 90 of Iowa's 99 counties. Despite wartime concerns, it was still the only "vacation" many women would get from "the million and one little things that are found in the everyday work of a farm wife." That year women met with members of the Women's Land Army, a federal wartime program designed

40. Mission for a Million Farmers (Chicago, 1944).

41. "VICTORY in the Hands of Women," Iowa Farm Bureau Federation Women's Committee Records, MS 189, IFBF Records; Newcomer, "Please Pass the Ammunition!" 7. 
to place young women as agricultural laborers in areas suffering from labor shortages. The Farm Bureau women also toured the state Farm Bureau offices and met with male leaders to address the question of women's place in the IFBF. The main consensus was that women were still most important in the areas of rural development and membership. They addressed the question again in 1944 and concluded that women's place in the organization was "anywhere" because they had "stepped in the shoes still warm from the feet of their war-bound men." By the following year, the women began to answer the question with increased fervor. $^{42}$

In 1945 the IFBFWC canceled the summer conference in light of wartime shortages. It opted instead to hold a series of nine smaller conferences in each district, attended by District Committeewomen and Extension leaders who "rode the circuit." A total of 450 farm women attended the nine conferences, where IFBFWC leaders found strong opinions about women's place not only in the IFBF, but also in the postwar world. At one conference in Chariton, the women concluded that they had "more to say than they used to have" on issues related to stable agricultural policies and prices, legislation on rural health and education, and the need for responsible soil conservation practices. "Women are partly to blame for low standards in farm homes of Iowa," they declared, "with their silly martyr-complex making them feel self-righteous using 'Gay 90 's' equipment when the farm is highly mechanized." To this, Newcomer added that "thinking does not have gender or age," and women's activism was essential in maintaining price structure and high incomes. ${ }^{43}$

IOWA FARM BUREAU WOMEN acted with new vigor in the immediate postwar years. In November 1945 Newcomer wrote that this was the time for increased action; no farm family could afford to "sit sunning itself in the false glow of a wartime prosperity." She challenged the IFBF leadership to reach out to

42. Bess Newcomer, "Country Culture Clinic," IBF 8 (August 1944), 5.

43. Bess Newcomer, "Brain Derbies for Farm Women," IBF 9 (August 1945), 6. In 1945 wartime shortages also affected the Iowa Bureau Farmer. The magazine had to use a smaller paper size and discontinue using glossy paper for the cover. "Bureau Farmer Goes to War," IBF 8 (April 1944), 5. 
farm families and to plan programs with enough depth that they "become part of [farm families] and their bright future." This new vitality among Farm Bureau women may be attributed to their wartime experiences, but is more likely due to their increased levels of organization since 1937 and Sayre's ability to recruit and train farm women to be active members. ${ }^{44}$

By 1945, the summer conference had become a regular event, as had separate meetings for women at the IFBF annual conferences in Des Moines. At the 1945 annual conference, the Women's Committee focused on programs concerning leadership, world relations, public relations, $4-\mathrm{H}$ clubs, health, and education. Such programs were hardly new to the IFBFWC, but the prosperity of the war years, combined with fears of a postwar depression, prompted it to step up demands for improved standards of living in rural areas. ${ }^{45}$

Newcomer's columns reflected the new energy on the part of the Women's Committee. In October 1946 she wrote that women wanted "more discussion of issues in more township meetings," and they wanted these exchanges to lead to "wellseeded resolutions that can be combined for county resolutions and threshed out for state and national policies." Newcomer's columns continued to focus on specific issues, such as the dangers of inflation and the need to fine tune farm policy in order to ensure better standards of living for farm families. In March 1947 she supported Farm Bureau efforts to ensure the extension of the Steagall Act, a measure passed in 1942 to guarantee wartime price supports for two years following the end of the war. Newcomer stated that legislators needed to prevent an agricultural depression because "it is only fair that farmers, who, year after year, have bent every energy to meet government-set goals in production have every right to expect government-promised supports to be met." ${ }^{146}$

44. Bess Newcomer, "Parable of the Apple Peddlers," IBF 9 (November 1945), 4.

45. Gladys Skelley, "Farm Homemakers Meet," IBF 9 (December 1945), 10.

46. Bess Newcomer, "Independent . . . and Broke," IBF 10 (October 1946), 7; idem, "Gnats and Camels," IBF 11 (March 1947), 20-21. For more on the Steagall Act, see The United States Senate Committee on Agriculture, Nutrition, and Forestry, 1825-1998: Members, Jurisdiction, and History (Washington, DC, 1998), chap. 5, "War, Peace, and Prosperity: 1940-1959." 
Building and maintaining an active membership consumed the IFBF and the IFBFWC between 1945 and 1950. That was the essential element for achieving the women's goals, as civic improvement usually required local consensus. Membership more than doubled during the war, from 40,590 in 1940 to 90,051 in 1945. In 1946 the IFBF set a state quota of 100,000 families, which it achieved by April of that year. In 1947, when membership reached nearly 122,000 , the IFBF experienced the largest annual increase in membership since its founding. Available sources do not reveal a specific reason for this increase, but growing membership numbers could be attributed to a number of causes. Radio broadcasts, as well as better roads and automobiles, allowed Farm Bureau women to initiate more extensive membership drives. Fears of a postwar depression may have prompted many farm families to become politically active. The greater availability of cash incomes for farm families during that period also may have allowed more families to afford dues. ${ }^{47}$

Regardless of the reasons for the growth, Newcomer often reminded her readers that increased membership did not necessarily imply a stronger organization. In April 1946 she wrote, "We should be concerned that our organization be fine-textured as well as big." If women had regular meetings without a strong action plan, she believed, they were acting only as a social club and would fail to make use of opportunities in the Farm Bureau. She was very critical of women who did not take advantage of the public forums offered by the IFBF to express their concerns on agricultural, political, and social issues. In November 1946, she reminded leaders that "we cannot afford to let this rich gift of voluntary leadership gather dust on the shelf." The membership numbers do not indicate how many more women became active in the postwar years, but the increased energy of the IFBFWC indicates that it surely benefited from the trend. ${ }^{48}$

In 1947 the Women's Committee experienced another change in leadership. During the summer conference, Sayre announced her election to the presidency of the Associated Country Women

47. Tontz, "Memberships of Farmers' Organizations," 156; Official Bulletin of the Iowa Farm Bureau Federation, October 1945, 1; ibid., May 1946, 1; ibid., April 1947, 1. 48. Bess Newcomer, "The Leaven and the Lump," IBF 9 (April 1946), 14; idem, "New Blood in Our Veins," IBF 9 (November 1946), 9. 
of the World (ACWW) and resigned as IFBFWC chair. The committee appointed Amanda "Peg" Eliason, the Seventh District Committeewoman from Letts, to serve the remaining three years of Sayre's term. Because Sayre's programs were well established and had the support of the committeewomen, the transition in leadership once again appeared seamless. Delegates at the summer conference elected to continue the 1947 programs into 1948, and to expand programs on international relations. In addition to continuing their contributions to the Pennies for Friendship campaign, they called for studies of various countries and trade policies, as well as designating International Relations chairs at the township level. Otherwise, the women's program continued to promote leadership, homemaking, youth programs, health, safety, and recreation."

Under the leadership of Eliason, who had earned a degree from Northwestern University and taught music in public schools for several years before her marriage, education took center stage. Eliason promoted a scholarship program that funded college educations for rural youth interested in becoming teachers, and she sponsored educational radio broadcasts for women. School consolidation became the central issue in 1946, and with it came debates on taxes, rural roads, libraries, and school lunches. According to IFBF member Ellen Hartnett, 40 percent of rural children never reached high school, and of those who did, only 43 percent graduated. In contrast, 85 percent of urban children attended high school and 65 percent graduated. Hartnett believed that rural people avoided the issue because reorganization would require higher taxes to support the required facilities, roads, and personnel, but she argued that once they began to lobby for school consolidation, tax laws would also change and the state would improve rural roads. ${ }^{50}$

49. Groves and Thatcher, The First Fifty, 58; "F.B. Women Set 1948 Goals," Official Bulletin of the Iowa Farm Bureau Federation, July 1947, 1.

50. "Annual Report for Progress," Iowa Farm Bureau Federation, 1950, MS 105, IFBF Records. By 1950, the IFBFWC had given scholarships to 72 students to become teachers. Ellen Hartnett, "Are You Ready for Action on School Program?" Official Bulletin of the Iowa Farm Bureau Federation, October 1946, 2. That year the Women's Committee celebrated one small step toward school improvement when Congress approved the National School Lunch Program, sponsored by the Department of Agriculture. Not only did the program guar- 
In 1948 Newcomer called for the immediate reorganization of rural schools, despite bad roads and tax laws. While rural high schools struggled to retain pupils, she argued, they lost tuition monies to schools in towns, which were overcrowded with rural students seeking better opportunities. She claimed that rural people could not be realistic about maintaining struggling rural schools as long as they sent their children to town for higher quality educations. Education was a central part of all IFBFWC programs, and members continued to promote reorganization and consolidation through the $1950 \mathrm{~s}^{51}$

BY THE LATE 1940s, Farm Bureau women no longer questioned whether they were an integral part of the organization, although they continued to reaffirm their place. In 1946 Newcomer recognized that women faced limitations in the organization and that they shaped IFBF policies only indirectly. Rather than blaming Farm Bureau men, she attributed women's limitations to the unstable state of agriculture. Farm women shared in the work of their husbands, and therefore in the business of farming. "In short," she wrote, "WE BELONG." Although they did not challenge traditional gender roles, IFBFWC women urged farm women to be active in their communities and to take a sincere interest in agricultural issues. The women took their roles as educators and social reformers seriously, and through the IFBF they learned leadership and organizational skills they might not have acquired otherwise. ${ }^{52}$

antee nutritious meals for children from low-income families, but it also provided new markets for agricultural produce.

In April 1948 the IFBFWC began monthly broadcasts on radio station WOI in Ames. The District Committeewomen took turns planning and presenting programs for The Women's Forum, hosted by Martha Duncan, which aired on the first Tuesday of every month. In the first broadcast, presented by Stella Inman of the Second District, the women first recognized the special and rare opportunity for homemakers to "approach a 'live' microphone," and then outlined their plans to petition for rural health. The next show in May, presented by Christine Floyd Dittmer of the First District, included a discussion on world trade. See "On the Air!! Farm Bureau Women Stage Radio Shows over WOI Each Month," IBF 11 (May 1948), 32.

51. Bess Newcomer, "Rustic Ruminations," IBF 11 (September 1948), 15.

52 Bess Newcomer, "She Married a Farmer," IBF 9 (August 1946), 8; McDonald, Ruth Buxton Sayre, 59. Sayre repeatedly rejected the idea of allowing IFBF 
During the 1950s, the lives and responsibilities of farm women changed tremendously. They adopted labor-saving appliances, gardened less, scaled down dairy and egg production, and exchanged their roles as farm producers for roles as consumers and business partners. In 1949, in keeping with the postwar resurgence of the feminine ideal in the United States, the Iowa Bureau Farmer introduced a new section in the magazine titled, "The Bureau Farmer's Wife." The section included articles on topics of specific interest to women-family issues, clothing, food, and other information about the home and family-that closely resembled the women's programs from the 1920s. Newcomer's articles, which had previously been featured in the opening pages, were nestled in among articles on news of the IFBFWC and other women's issues. This was not imposed on the Farm Bureau women by male editors, however, but rather came about through the efforts of Marjorie Burke, who worked through the Information Department to publicize women's activities.

The emergence of a women's section in the Iowa Bureau Farmer was consistent with trends in extension publications and agricultural periodicals in the 1950s. Historian Katherine Jellison has illustrated how during that period extension agents, advertisers, and journalists increasingly promoted new technologies by promising farm women a lifestyle similar to that of urban women. Farm wives could be free from the drudgery of farm life, enjoy abundant free time, and become "homemakers," thanks to indoor plumbing, electricity, washing machines, refrigerators, telephones, and the countless new appliances available in the postwar period. Yet Jellison also found that while farm women welcomed new technologies, they resisted idealized images and notions that they should retreat into a life of leisure disconnected from the business of the farm. Rather, farm women often became involved in managing the business of the farm, or they took jobs in town to secure a cash income. ${ }^{53}$

queen contests, although the topic often came up in Executive Committee meetings. Sayre successfully persuaded her male colleagues on the Executive Committee that the time and energy required to promote such a contest could be better spent sponsoring more meaningful activities.

53. Katherine Jellison, Entitled to Power: Farm Women and Technology, 1913-1963 (Chapel Hill, NC, 1993). 
Similarly, although the editors of the Iowa Bureau Farmer relegated women's issues to a special section of the magazine, the policies and practices of the IFBFWC show that it still considered women central to the overall organization. In 1953 the Women's Committee operated on a budget of nearly $\$ 30,000$, more than twice what the Farm Bureau allocated to either the Legislative, Research, or Youth Departments. In 1955, after IFBFWC chairwoman Christine Inman overheard an implement dealer refuse to tell women the prices of farm machinery because it would "scare" them, she wrote, "Farm women are aware of costs and prices in their close partnership in the family farm business and they also have a great deal of influence as to how the farm income is spent." Women from the general membership, who often wrote letters to IFBF President E. Howard Hill, as well as to the editor of the Iowa Farm Bureau Spokesman, also expressed concerns for agricultural policies. Throughout the 1950s, women wrote letters on the importance of soil conservation, as well as on the problems associated with agricultural surpluses and the need for price controls. They criticized political leaders for failing to act in the face of an economic downturn, and they suggested IFBF resolutions related to politics and agriculture. ${ }^{54}$

THE 1950s marked yet another important transition within the organization. By 1950, Ruth Sayre and the committeewomen who had helped develop programs in the 1930s and 1940s had either retired or moved on to other organizations. They did not leave the IFBFWC entirely behind, however, and often expressed fears that they had left a void in leadership. Newcomer and Sayre continued to correspond through the 1960 s, and they often reflected on changes within the IFBFWC, sometimes noting that the current women leaders did not have the same energy or

54. Christine Inman, "How Do You Decide Whether Money Goes into Farm Machinery or Home?" Iowa Farm Bureau Spokesman 21 (4/30/1955), 12 (hereafter cited as Spokesman). See also Ruth van Alstine to E. Howard Hill, 10/4/ 1955, E. Howard Hill Papers, RS 21/7/4, University Archives, Parks Library, Iowa State University, Ames; Spokesman 22 (11/5/1955), 2; ibid. 22 (3/24/1956), 4; ibid. 23 (10/13/1956), 4; ibid. 23 (9/22/1956), 4; ibid. $26(8 / 20 / 1960)$, 4; ibid. 28 (11/18/1961), 4. The Iowa Farm Bureau Spokesman replaced the Iowa Bureau Farmer as the official organizational publication in 1953. 
desire to improve rural life. As she ended her stint as a writer for the Iowa Bureau Farmer, Newcomer seemed to become more dismayed with agricultural trends toward large, mechanized farms. In her final column, in October 1950, she commented that many farmers could not keep up with demands for modernization. Farm families, she urged, should "discard the fallacy that the most improved farm is the one with the biggest collection of merchandise. ${ }^{155}$

Even after Newcomer resigned her position as the Eighth District Committeewomen because her husband, Ralph, had suffered a stroke and required constant care, she retained an interest in rural and agricultural issues and a sentimental attachment to the IFBFWC, simply shifting her activism from state to local activities. Throughout the 1950s and 1960s, she became involved with the local school board and tax conference, which she found to be a "good proving ground" for her "basic Farm Bureau beliefs." Overall, her experiences illustrate how the IFBFWC consistently promoted rural women's activism and how the women in the organization helped set a precedent for women's involvement in agricultural issues in Iowa. ${ }^{56}$

BETWEEN 1921 AND 1951, the IFBFWC offered Iowa farm women opportunities to become involved in the organization and within their communities. Yet the IFBFWC's activities and policies also evolved over time to address the changing needs of farm women. During the 1920s the Iowa Farm Bureau emphasized homemaking activities for women that eventually led to greater social and political activism between 1937 and 1950. During those latter years the IFBFWC consolidated its statewide efforts through standard handbooks, summer conferences, and articles in the Iowa Bureau Farmer. Under the leadership of Ruth Sayre, Iowa Farm Bureau women drew on their experiences of economic hardship, especially during the Great Depression, to demand higher standards of living in rural areas. The challenge for the next decade was for the IFBFWC to sustain and build on

55. Newcomer, "Rustic Ruminations," 22.

56. Newcomer to Sayre, December 1952, Ruth Buxton Sayre Papers, State Historical Society of Iowa, Iowa City. See also Dan Murphy, "Where Are We?" Spokesman 30 (7/4/1964), 12; Newcomer to Sayre, 12/15/1969, Sayre Papers. 
the groundwork that had been established, and to decide whether to develop new programs or continue what seemed to work.

Several factors precipitated the shift from practical activities to social and political activism. The consistent leadership of women such as Sarah Elizabeth Richardson and Ruth Buxton Sayre, who chaired the IFBFWC between 1937 and 1948, provided stability within the organization. At the same time, new technologies and higher expectations for standards of living provided women with a distinct sense of purpose. Because most farms lacked electricity, running water, and other amenities, the women saw rural conditions as inferior to urban standards. In 1930 only 24 percent of rural homes in Iowa had indoor plumbing, and only 21 percent were wired for electricity. Even by 1945, only 31 percent had indoor plumbing and 58 percent had electricity. For Farm Bureau women, these conditions raised important questions regarding rural health, safety, and education. They believed that there was a definite need for their activism, and they considered their work in expanding social programs essential to the IFBF mission of promoting better farm living. ${ }^{57}$

During these same years, the women's club movement reached its peak in the United States, and the farm women of the IFBFWC, like their urban, middle-class counterparts, found civic and political power, as well as important social networks, through organization. Throughout the 1920s, the IFBFWC worked closely with members of the Federated Women's Clubs of Iowa, a largely urban organization that worked on civic improvements and political issues. Farm Bureau women sought to recreate such activism in the countryside. In 1937 Sayre declared that it was "not enough today for a woman to cook and bake and sew." If women organized as community housekeepers who worked for the betterment of agriculture and rural life, they would "radiate a power and a strength that stretches far beyond our individual horizons. ${ }^{158}$

57. Jellison, Entitled to Power, 154; Agricultural Statistics (Washington, DC, 1945), 410-11.

58. IFBM 5 (November 1923); IFBM 6 (February 1925); Peter Hoehnle, "Iowa Clubwomen Rise to World Stage: Dorothy Houghton and Ruth Sayre," Iowa Heritage Illustrated 83 (2002), 44; Ruth Buxton Sayre, "Partners in Progress," Iowa Farm Bureau Federation Administrative Report (1937), 23, 24, IFBF Rec- 
Perhaps it was their desire to reach wide audiences, urban as well as rural, that enabled Farm Bureau women to gain mass appeal. Although well educated and exceptional in their leadership experiences, women leaders at the state level spoke and wrote in terms of what ordinary people could do to solve problems. They did not wish to tout themselves as experts, but rather they emphasized the shared experiences of all farm women: the work, the uncertainty, and the unique qualities of rural life. Across the nation, Farm Bureau leaders worked to broaden the organization's appeal by encouraging non-partisan efforts to strengthen the rural community, and the leaders of the IFBFWC played an integral role in promoting that philosophy.

The Women's Committee encouraged traditional gender roles and promoted conservative politics, but it did not necessarily relegate women to subordinate positions. In its first 30 years, the IFBFWC expected its members to learn about issues, to respond to political and social conditions, and to act as the public relations arm of the IFBF. Furthermore, the IFBFWC expected members to evolve as changes in technology, farm policy, and world events reshaped their lives. This conclusion rests on the premise that the term activism must be extended beyond radicalism, protests, and withholding actions to encompass activities such as home demonstration programs and educational efforts. More importantly, when the term activism is applied to rural women's efforts, it must not be immediately connected to issues concerning gender equity. Instead, scholars must consider the agricultural context in which farm women worked. Women accepted dominion over domestic and social issues because the complementary nature of the IFBF and the IFBFWC mirrored the division of labor on many farms, where men and women focused

ords. In contrast, the Women's Auxiliary of the Iowa Farmers Union actually opposed association with urban women's clubs on the grounds that wealthy urban women used their political clout to dictate government policy. One of its official purposes as an auxiliary was to "counteract the influence of Women's Clubs and other reactionary groups who are working for themselves and not for farmers." In May 1931 Lillie Blumgren, a member of the Women's Auxiliary, wrote that Extension workers were the product of "eastern capitalists and politicians" who passed rural legislation at the suggestion of city club women. She concluded by demanding that the ladies of the IFU "develop a class consciousness," and develop a "real farm women's organization" that would truly fight for agriculture. See Iowa Union Farmer 14 (5/20/1931). 
on separate tasks for the sake of the whole. Women's efforts to improve rural standards of living could not easily be separated from issues concerning commodity prices, production, and technology, because those factors directly related to the women's abilities to improve their homes and communities. 
Copyright of Annals of Iowa is the property of State of Iowa, by \& through the State Historical Society of Iowa and its content may not be copied or emailed to multiple sites or posted to a listserv without the copyright holder's express written permission. However, users may print, download, or email articles for individual use. 